\title{
3. PRE-CRUISE AND SITE SURVEYS: A SYNTHESIS OF MARINE GEOLOGICAL AND GEOPHYSICAL DATA ON THE CÔTE D'IVOIRE-GHANA TRANSFORM MARGIN ${ }^{1}$
}

\author{
Christophe Basile, ${ }^{2}$ Jean Mascle,${ }^{3}$ Françoise Sage,${ }^{3}$ Geoffroy Lamarche, ${ }^{4}$ and Bernard Pontoise ${ }^{4}$
}

\section{INTRODUCTION}

Present-day knowledge of the northern Gulf of Guinea continental margin (Fig. 1) results from several periods of marine geological and geophysical research. An exploration stage was initiated in the early 1970 s, and regional surveys of the Côte d'Ivoire margin and Ghanaian continental slope were conducted into the middle 1980s. These regional surveys were followed by detailed surveys of large areas of the Côte d'Ivoire-Ghana Marginal Ridge and by multichannel seismic reflection and wide-angle seismic data acquisition. Most recently, the steep southern slope of the Marginal Ridge has been the main target of a deep-sea submersible cruise.

During the early 1970s, a few multichannel seismic reflection regional lines were recorded across the Côte d'Ivoire margin by Comité d'Etudes Pétroliéres Marines (CEPM) and Institut de Physique du Globe de Paris (IPGP) during Géoguinée and Bénin cruises on board the $J$. Charcot. These cruises resulted in a structural reconnaissance of parts of the deep continental margin and its southern bordering ridge (Delteil et al., 1974). The structural connection between the Marginal Ridge and the fossil Romanche Fracture Zone was first pointed out by Fail et al. (1970). These data were complemented by underway single-channel seismic profiles, as well as by a few dredging and coring samples collected during the African margin reconnaissance Walda cruise, also conducted on board the J. Charcot (Mascle, 1976), and by a survey organized by Woods Hole Oceanographic Institution on board the Atlantis II (Emery et al., 1975).

Conducted in 1983 by the Groupe d'Etudes de la Marge Continentale et de l'Océan (GEMCO), the Equamarge I cruise (Suroit) was chiefly dedicated to the study of the transition zone between the Romanche Fracture Zone and the continental transform margin up to

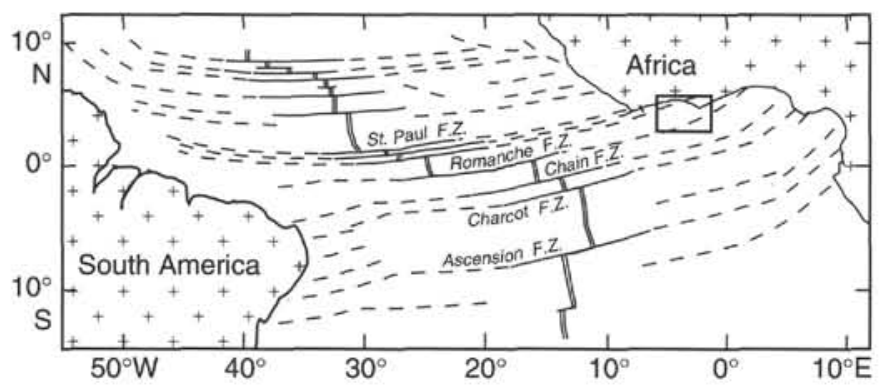

Figure 1. Sketch of the equatorial Atlantic fracture zones and associated continental margins. The continental margins off Côte d'Ivoire and Ghana are genetically associated to the Romanche Fracture Zone. The box locates Figures $2-4$.

Mascle, J., Lohmann, G.P., Clift, P.D., et al., 1996. Proc. ODP, Init. Repts., 159 College Station, TX (Ocean Drilling Program).

'CNRS-ERS129, Institut Dolomieu, 15 rue M. Gignoux, Université Joseph Fourier. 38031 Grenoble Cedex, France. Basile@grenet.fr

CNRS-URA718. GEMCO-Laboratoire de Géodynamique Sous Marine, BP48. 06230 Villefranche-sur-Mer. France. Mascle: mascle@ccrv.obs-vlfr.fr

${ }^{4}$ ORSTOM-Laboratoire de Géodynamique Sous Marine, BP48, 06230 Ville franche-sur-Mer, France, the Ghanaian continental slope. Leg 159 potential target areas were surveyed using single-channel seismic lines together with new sampling attempts (Fig. 2) (Blarez et al., 1987; Blarez and Mascle, 1988). In 1988, during the Equamarge II cruise, also organized by GEMCO, most of the Côte d'Ivoire-Ghana Marginal Ridge was surveyed using the swath bathymetric system and complementary geophysical tools on board the J. Charcot (gravimetry, magnetism, and single-channel seismic reflection). A dense grid of single-channel seismic lines was recorded in two target areas, including the ones of the future Ocean Drilling Program (ODP) Sites 959, 960, 961, and 962 (Fig. 2). The first area extends to the east of the Côte d'Ivoire-Ghana Marginal Ridge, near to its connection with the Ghanaian shelf and slope; the second area covers most of the Marginal Ridge, including its western extremity toward the deep abyssal plain. Besides detailed bathymetric maps, the recovered data allowed structural and gravimetric mapping that considerably increased understanding of the tectonic style and crustal structure (Basile et al., 1989; Popoff et al., 1989; Pontoise et al., 1990; Basile et al., 1992 and 1993).

In 1990, GEMCO and ORSTOM conducted two joint surveys on board the Nadir off east Côte d'Ivoire and west Ghana (Fig. 2). The Equasis leg was devoted to multichannel seismic (MCS) profiling across and along strike of the divergent and transform margins and to surveying sites for potential deep drilling (Mascle et al., 1995; Lamarche et al., in press). The Equaref leg recorded wide-angle seismic data using a network of ocean-bottom seismometers (OBS) deployed along MCS lines across and parallel to the Côte d'Ivoire-Ghana Transform Margin (Sage, 1994; Mascle et al., 1995). Complementary refraction crustal data were obtained in the same area by the $C$. Darwin in 1991 as part of a joint program between the Institute of Oceanographic Sciences (UK) and ORSTOM/GEMCO teams.

Finally, in June 1992, during the Equanaute cruise on board the Nadir, the southern marginal Côte d'Ivoire-Ghana Ridge slope was investigated using the deep-sea submersible Nautile from IFREMER. Fourteen deep dives were performed in water depths ranging between $4950 \mathrm{~m}$ and $2200 \mathrm{~m}$, for a total distance surveyed on the seafloor of about $75 \mathrm{~km}$ (Mascle et al., 1993, 1994).

\section{BATHYMETRY}

The combination of GEBCO plotting sheets and $12-\mathrm{kHz}$ data collected during the Equamarge I cruise allowed Blarez (1986) to produce the first general bathymetric map of offshore Côte d'Ivoire and Ghana, including the deep margin (Fig. 3). The main morphologic features are, from north to south:

1. A narrow continental shelf, ranging from a few $\mathrm{km}$ offshore Côte d'Ivoire to about $70 \mathrm{~km}$ offshore Ghana.

2. A well-developed continental slope and rise (between $200 \mathrm{~m}$ and approximately $4600 \mathrm{~m}$ of water depth) known as the Deep Ivorian Basin (DIB).

3. A prominent, high-standing (up to $2000 \mathrm{~m}$ ) marginal ridge trending southwest to northeast, known as the Côte d'IvoireGhana Marginal Ridge. The ridge forms the southern boundary of the DIB and towers above, locally by more than $3000 \mathrm{~m}$, 


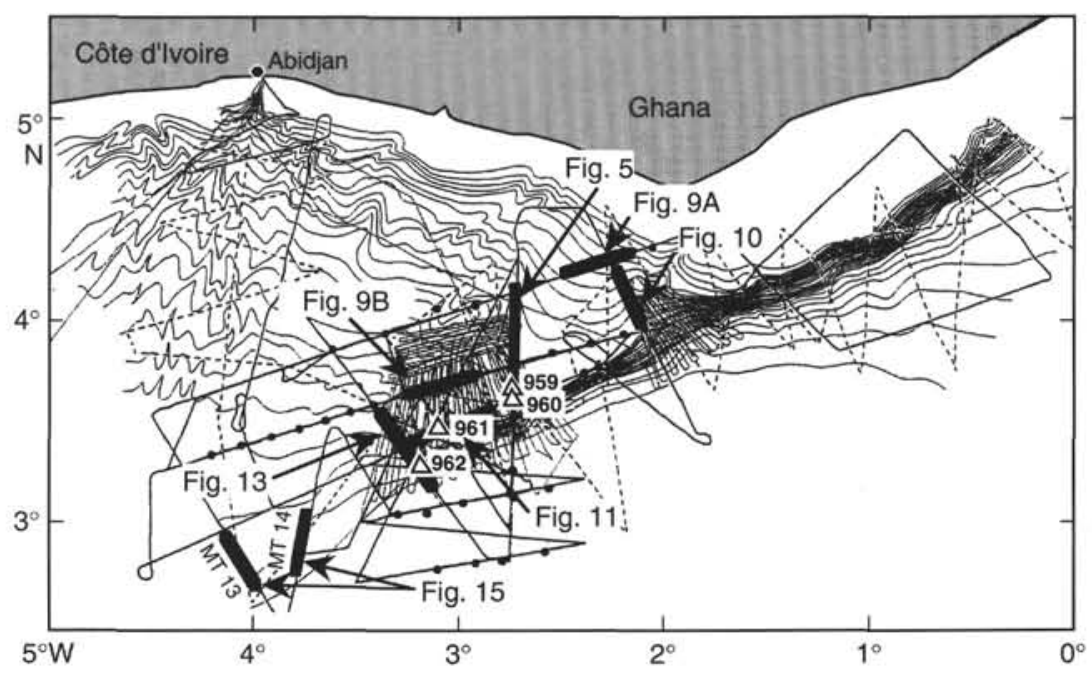

Figure 2. Geophysical data collected since 1983 on the Côte d'Ivoire-Ghana margin shown on a simplified bathymetric map (bathymetric contour interval 200 $\mathrm{m}$, mercator projection at the equator). Dashed lines: single-channel seismic lines (Equamarge 1, 1983); thin lines: single-channel seismic lines and swath bathymetry (Equamarge II, 1988); solid lines: multichannel seismic lines (Equasis, 1990); solid circles: location of OBS deployments for seismic wide-angle experiments (Equaref, 1990); open triangles: Iocation of Leg 159 sites.

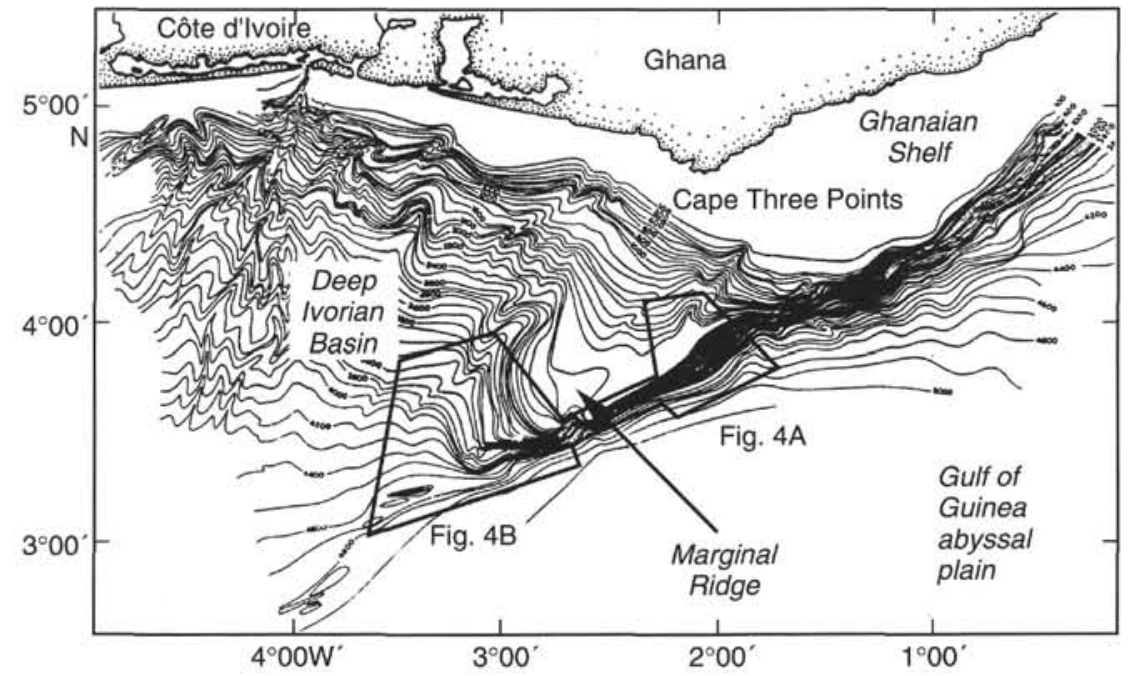

Figure 3. Bathymetric map of the Côte d'Ivoire-Ghana margin; bathymetric interval $100 \mathrm{~m}$ (after Blarez, 1986). Location of Figure 4A, B is outlined.

the adjacent southern Gulf of Guinea Abyssal Plain, which averages almost $5000 \mathrm{~m}$ water depth. Eastward the ridge connects with the very steep Ghanaian continental slope, whereas toward the southwest it progressively deepens and passes into a series of small abyssal hills aligned with the fossil Romanche Fracture Zone. In fact, the transition between the Ghanaian Platform and the abyssal plain is remarkably narrow, in places less than $20 \mathrm{~km}$ wide.

The detailed swath bathymetry obtained during the Equamarge II cruise covers two areas across the Marginal Ridge, one at its eastern corner, near the Ghanaian Platform, and another along most of the ridge itself and parts of the adjacent DIB (Figs. 3, 4). The eastern sector offers a relatively subdued slope $\left(20^{\circ}\right)$ cut by numerous canyonlike valleys (Fig. 4A). To the west, the continental slope becomes almost linear ( $\mathrm{N} 60^{\circ}-\mathrm{N} 65^{\circ}$ trending) and very steep, locally dipping up to $50^{\circ}$ (west of Fig. 4A). This passes southwestward into a still steep but deeply dissected slope segment where several north-south trending promontories are seen (Fig. 4B). From this area, and toward the west, the southern slope of the ridge, as well as the ridge top, progres- sively deepen (Fig. 4B). The ridge top is a flat and narrow plateau that culminates in $2000 \mathrm{~m}$ water depth; northward, toward the DIB, the Marginal Ridge shows a gentle and regular west-dipping slope cut only by a large valley, sub-parallel to the ridge general strike. ODP sites are located just north of the ridge top, at $2102 \mathrm{~m}$ (Site 959) and $2085 \mathrm{~m}$ (Site 960) water depth, near the ridge axis at a water depth of $3315 \mathrm{~m}$ (Site 961) and in the vicinity of a small hill that can be seen at $4600 \mathrm{~m}$ water depth, west of the ridge termination (Site 962) (Fig. 4B).

\section{MAGNETISM AND GRAVIMETRY}

Magnetic field intensity was recorded using towed proton magnetometers during most of the surveys conducted across the transform margin and its adjacent oceanic crust. Little can be extracted from these data since the area of study lies near the magnetic equator and has apparently always been located near low magnetic latitudes. No specified oceanic magnetic lineation has been determined with confidence within a large portion of the equatorial Atlantic, and, there- 
A
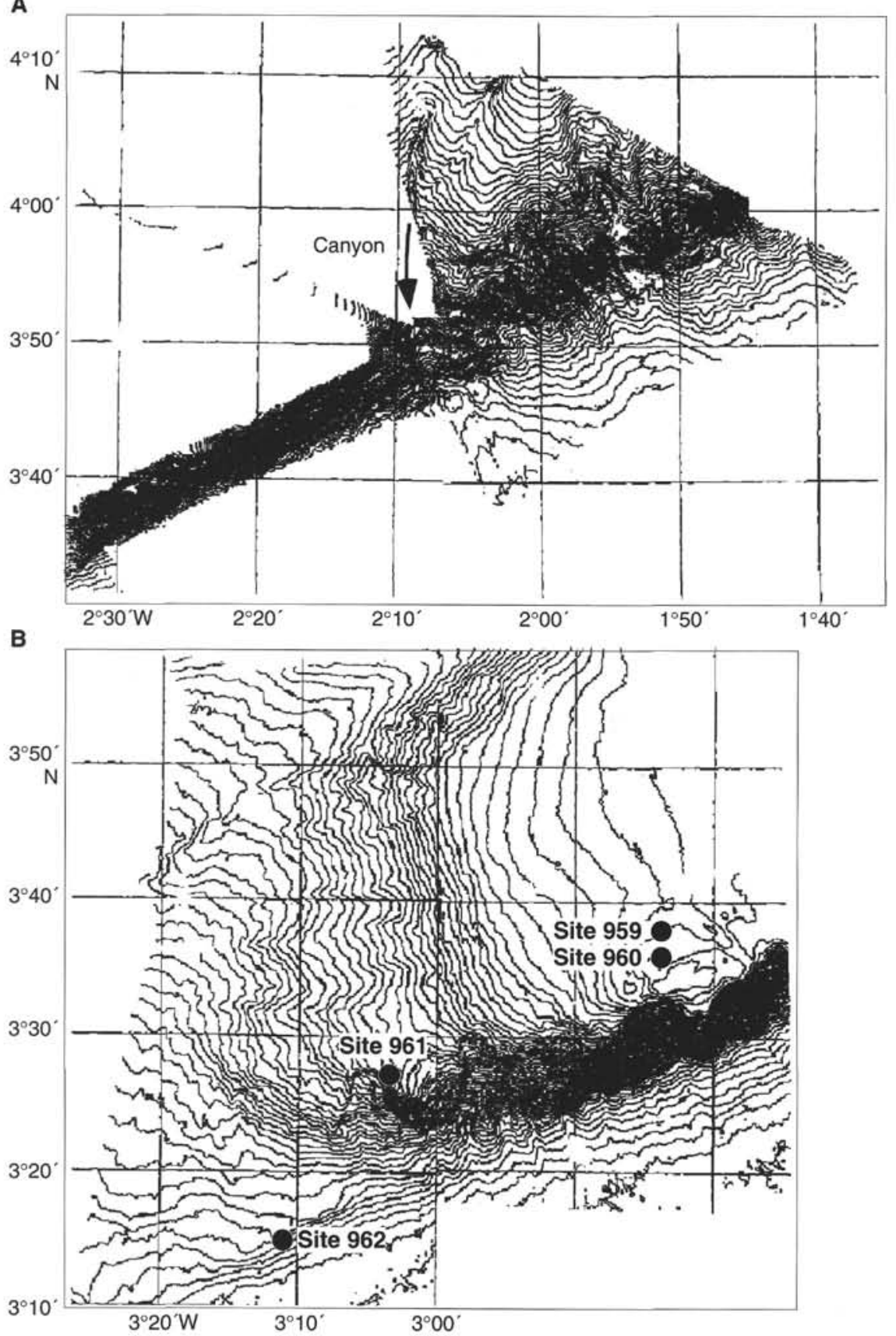

fore, precise age and rates of oceanic opening remain poorly constrained in the vicinity of the Côte d'Ivoire continental margin. Only a few subdued anomalies (less than $100 \mathrm{nT}$ ) are detected across the marginal ridge and bordering basins, and they are thought to reflect magnetic contrast caused by crustal depth variations (Pontoise et al., 1990).

Free-air gravity anomalies proved to be more useful and provided two-dimensional crustal models across the sharp ocean-continent transition underlined by the transform ridge (Pontoise et al., 1990). A significant positive free-air anomaly is clearly associated with the ridge itself, while a strong negative anomaly characterizes the continent-oceanic boundary (on the order of $100 \mathrm{mGal}$ peak to peak). This has been explained in terms of a narrow transition (less than $10 \mathrm{~km}$, according to Sage, 1994) between a slightly thinned continental crust beneath the central ridge domain $(20-22 \mathrm{~km}$ thick) and the adjacent and thin oceanic crust (4-5 km thick).
Figure 4. Swath bathymetric map (contour interval 10 m) of (A) the Ghanaian continental slope off Cape Three Points, and (B) the Côte d'Ivoire-Ghana Marginal Ridge and surrounding areas (see location on Fig. $3)$.

\section{SEISMIC REFLECTION DATA}

The dense network of continuous seismic reflection data collected since the early 1970s (Fig. 2) has probably made the Côte d'IvoireGhana transform one of the world's best-surveyed transform margin segments. These data provide crucial support for a better understanding of sedimentary processes, tectonic mechanisms and structures, as well as of proposed geological models based on timing estimates and seismic stratigraphic patterns through time.

The good seismic resolution and the close spacing of the Equamarge II lines (Fig. 2) were the basis of detailed mapping and analysis of the progressive sedimentary infilling of the DIB and bordering ridge shoulders as well as the basis of structural mapping of the transform domain (Basile, 1990; Basile et al., 1993).

Deeper penetrative multichannel seismic lines recorded in 1990 improved our knowledge of what was referred to as an acoustic base- 


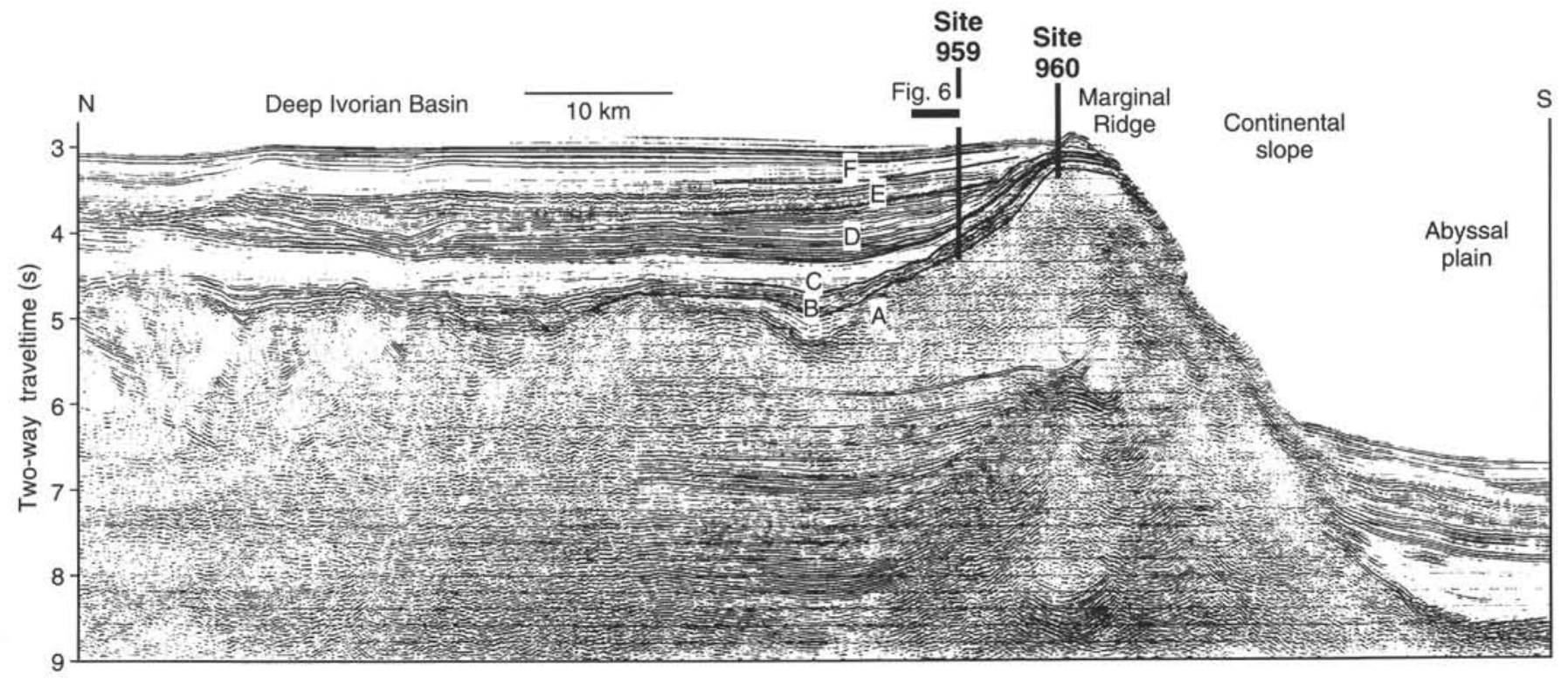

Figure 5. Migrated MCS section from Line MT02 across the Deep Ivorian Basin, the Marginal Ridge, and the abyssal plain (location on Fig. 2). Locations of Sites 959 and 960 are indicated. Main seismic units are shown.

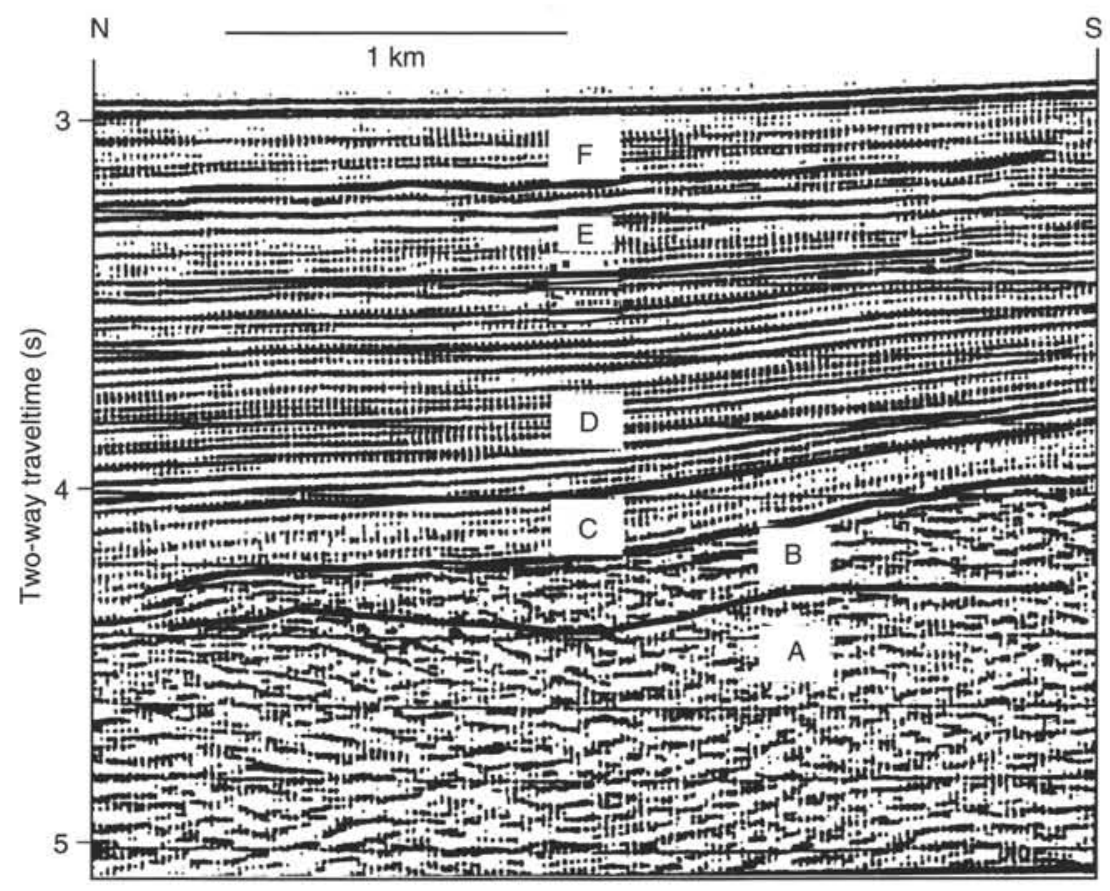

Figure 6. Main litho-acoustic units as defined by Basile et al. (1993) within the Deep Ivorian Basin and along the northern slope of the Marginal Ridge. Migrated MCS Line MT02 located on Figure 5.

ment (Blarez, 1986; Blarez and Mascle, 1988). These data demonstrated, as only inferred before, that the Marginal Ridge was made of a thick pile of deformed sediments with interval velocities of at least $3.6 \mathrm{~km} / \mathrm{s}$ (Fig. 5). These velocity values imply local thickness of the deformed sediments in excess of 3 to $4 \mathrm{~km}$. From the integration of seismic data, six main acoustic units have been distinguished (Fig. 6) (Basile et al., 1993):

1. A basal unit, referred to as Unit A, constitutes the syn-rift infilling of half-grabens seen beneath most of the DIB. Unit A, which shows a rather well layered and continuous acoustic facies elsewhere, exhibits a chaotic and discontinuous acoustic character near and within the Marginal Ridge. Directly exposed along the ridge southern slope, this sedimentary sequence is thought to constitute most of the ridge sedimentary pile. MCS profiles across the ridge demonstrate, however, that Unit A can be subdivided into three sub-units defined by successive angular unconformities. Moreover, changes in acoustic facies suggest differences in sediment type (proximal vs. 
more distal deposition environment), deformation intensity, and sediment provenance.

2. Unit B overlies Unit A unconformably in the DIB. It is absent over most of the ridge top, but thickens considerably and becomes more continuous toward the DIB where it represents the first post-rift sediment cover. Unit B, being postrift in the divergent domain and deformed nearby the transform Marginal Ridge, has been referred to as a "syn-transform" unit, coeval with the main transform tectonic activity (Basile et al., 1993).

3. The overlying Units $C$ through $F$ are only slightly affected by normal faulting, which probably owes its origin to gravitation-
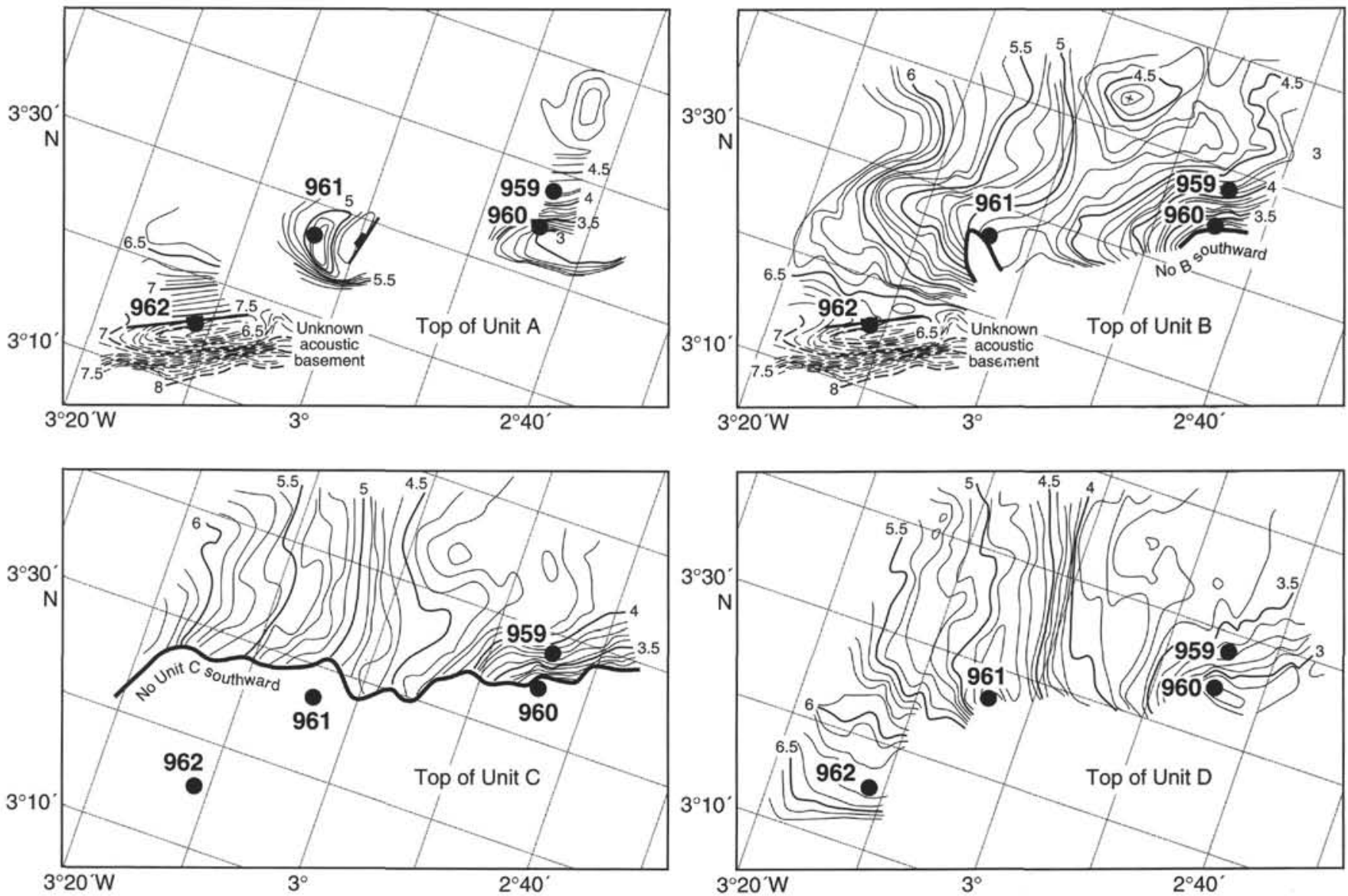

al sliding or differential compaction. These units either overlap the ridge slope (Units C and D) or lie directly on the ridge crest (Units E and F) (Fig. 7). Their arrangement is thought to reflect the vertical movement of the ridge (uplift and subsidence) through time.

\section{Tectonics}

Seismic reflection profiling has greatly improved our understanding of both the divergent and transform domain structural styles (Fig. 8). Within the DIB, extensional features such as half-grabens and

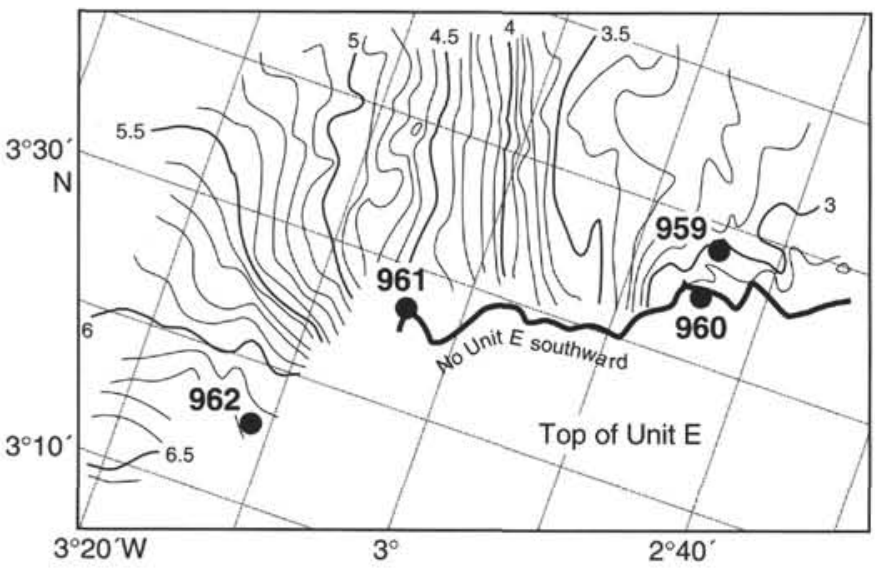

Figure 7. Maps, in two-way traveltime (s), of the top of main litho-acoustic units along the northern ridge slope and in the Deep Ivorian Basin; A, B, C, D, E refer to successive units as shown on Figure 6. Units A and B can only be discriminated on MCS lines. The top of A and/or B (top of the deformed sediments) is shown in Figure 8. 
Figure 8. Structural sketch of the Côte d'Ivoire-Ghana Marginal Ridge and surrounding areas. Contours are of two-way traveltime (s) to the top of the deformed sediments (Units A and B) (modified after Basile et al., 1993). Locations of Leg 159 sites are indicated by filled circles.

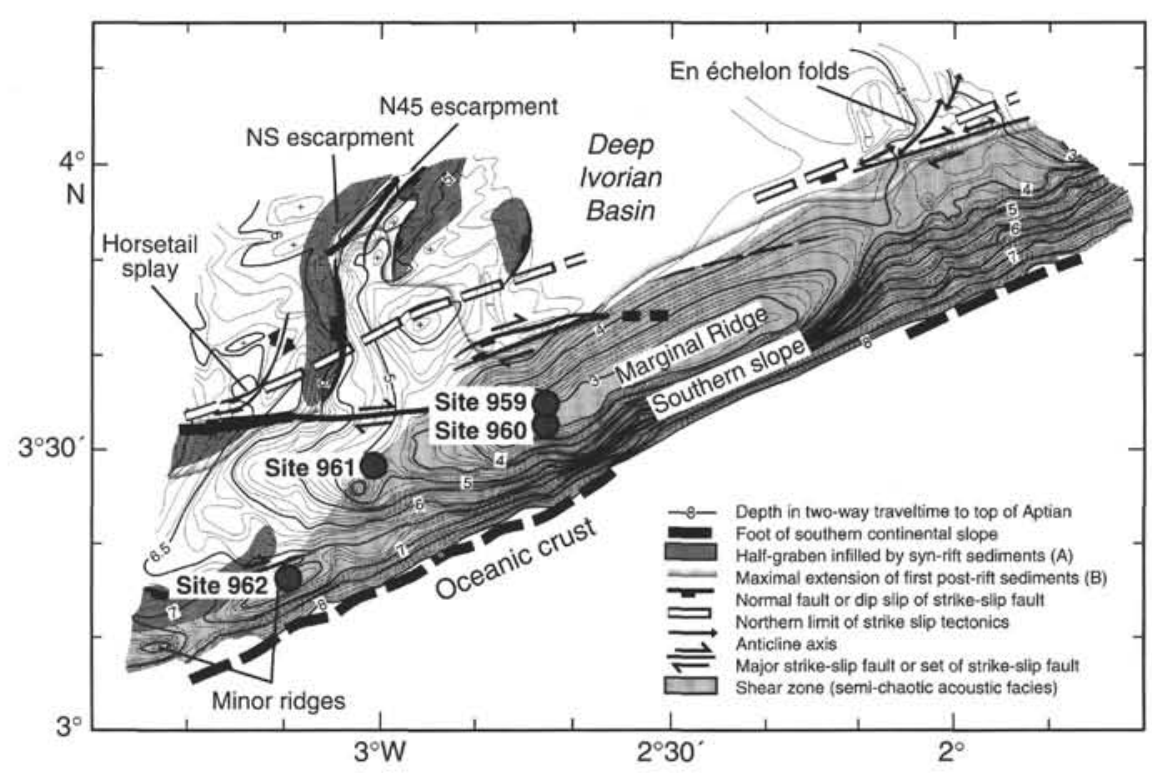

asymmetric tilted blocks are well imaged on MCS lines (Fig. 9). Block faulting shows a rather regular, 4- to 5-km spacing, comparable to that described in many divergent margin segments. We observed along longitude $3^{\circ} 05^{\prime} \mathrm{W}$, however, a west-dipping, northsouth trending, normal fault zone (vertical offset up to $1.5 \mathrm{~km}$ ) bounding two crustal blocks (Figs. 8,9B). This major structural break is coincident with a sudden crustal thinning (see "Wide-angle Seismic Data" section, below) and may be inherited from previous cratonic lineaments (Basile et al., 1993; Sage, 1994).

Transform-related tectonics vary notably along ridge strike from east to west. Near its connection with the Ghanaian Platform the paleo-transform margin is characterized by reverse faulting and associated gentle en échelon folds (Figs. 8, 10). From $2^{\circ} 10^{\prime} \mathrm{W}$ to $3^{\circ} 15^{\prime} \mathrm{W}$ the ridge is characterized by an acoustic basement-like high, trending $\mathrm{N} 65^{\circ}$, and progressively deepening westward and shifting toward an east-west direction. MCS data reveal that the ridge is also cut by a series of extensional rotated blocks quite similar and likely coeval to those of the northern divergent margin (Figs. 11, 12). Strike-slip faults are less easy to detect because they occur as subvertical features cross-cutting clastic and deformed materials (Figs. 5, 10). MCS line MT01 (Fig. 13), however, illustrates that near its western end, the fossil transform is still apparent as buried flower structures.

West of $3^{\circ} 10^{\prime} \mathrm{W}$, near the oceanic abyssal plain, the Marginal Ridge vanishes and seems to pass into a series of en échelon minor ridges, about $20-25 \mathrm{~km}$ in length, a few kilometers wide and less than $500 \mathrm{~m}$ in elevation, that also appear bounded by east-west trending strike-slip faults and associated tilted blocks (Figs. 8, 13, 14). Further west these elongated, almond-shaped bodies connect progressively with aligned acoustic basement highs, which presumably denote the path of the Romanche Fracture Zone (Fig. 15).

\section{WIDE-ANGLE SEISMIC DATA}

The dense network of seismic data recorded using digital OBS's across the DIB and its transform border (Fig. 2), together with gravity modeling, greatly constrains the interpretation of the continental and adjacent oceanic crust as well as the continent-ocean boundary (Sage, 1994; Mascle et al., 1995).

East-west crustal sections across the DIB display a rifted margin configuration. In the studied area the continental crust progressively thins westward from $18-20 \mathrm{~km}$ to $10-12 \mathrm{~km}$ near the base of the continental slope over a distance of approximately $200 \mathrm{~km}$ (Fig. 16). The section includes a 3- to 4-km-thick sedimentary cover overlying an upper continental crust ( 5.2 to $5.5 \mathrm{~km} / \mathrm{s}$ ) and a typical lower continen- tal crust ( 6.0 to $6.9 \mathrm{~km} / \mathrm{s}$ ). The overall crustal structure fits well with a progressive continental stretching, as recorded in the uppermost brittle continental crust by normal faulting and block rotation (Fig. 9). The maximum thinning, however, occurs west of $3^{\circ} 05^{\prime} \mathrm{W}$ where a major normal fault has been observed (Fig. 9B).

Deep seismic refraction experiments recorded along strike and over the Marginal Ridge indicate a comparable crustal structure (18$20 \mathrm{~km}$ crustal thickness to the east and 7-8 $\mathrm{km}$ to the west), with a zone of thinning near $3^{\circ} 05^{\prime} \mathrm{W}$ (Sage, 1994), similar to the one observed northward in the divergent basin. This supports the idea that the transform ridge may consist of an uplifted element of the adjacent DIB.

A crustal section across the transform ridge has been derived from both refraction data and gravimetric modeling (Sage, 1994; Mascle et al., 1995) (Fig. 17). It stresses the narrow ocean-continent transition and very steeply dipping Moho within a transition zone less than 10 $\mathrm{km}$ wide. Moho depths change by $12 \mathrm{~km}$ between the $20-\mathrm{km}$-thick continental crust and the abnormally thin adjacent oceanic crust ( 3.5 $\mathrm{km}$ thick, according to Sage, 1994).

\section{DEEP-SEA SUBMERSIBLE OBSERVATIONS AND SAMPLES}

Geological sampling was attempted successively along the steep Ghanaian continental slope during the three Walda, Equamarge I and II surveys. Meta-sediments, attributed to African Paleozoic units, and mylonites were retrieved by dredging along the very steep slope that bounds the Ghanaian Platform to the south (Fig. 3) (Mascle and Smit, 1974; Blarez et al., 1987). Only clastic sediments, chiefly coarse sandstones and siltstones, have been sampled along the southern ridge slope. Some of these samples showed evidence of syn-sedimentary deformation, with a few being dated as Albian based on ostracoda fauna. These samples suggested a sedimentary origin ("tectonized sedimentary wedge") for the Marginal Ridge (Blarez et al., 1987).

The recent deep-sea submersible Equanaute survey conducted in the area has greatly improved our understanding of the sedimentary environments and structural styles that prevailed during transform margin creation (Mascle et al., 1993, 1994). Sites 959 and 960 are located just a few miles north of an area visited downslope by dives EN8, EN9, EN10, and EN12. Site 962 is located three miles from the slope segment visited by dive EN14.

Numerous (165) rock samples collected in situ and the 75 hours of video recorded along $75 \mathrm{~km}$ of seafloor visited during 14 deep dives (Fig. 18) unambiguously demonstrate that the ridge slope is 
A

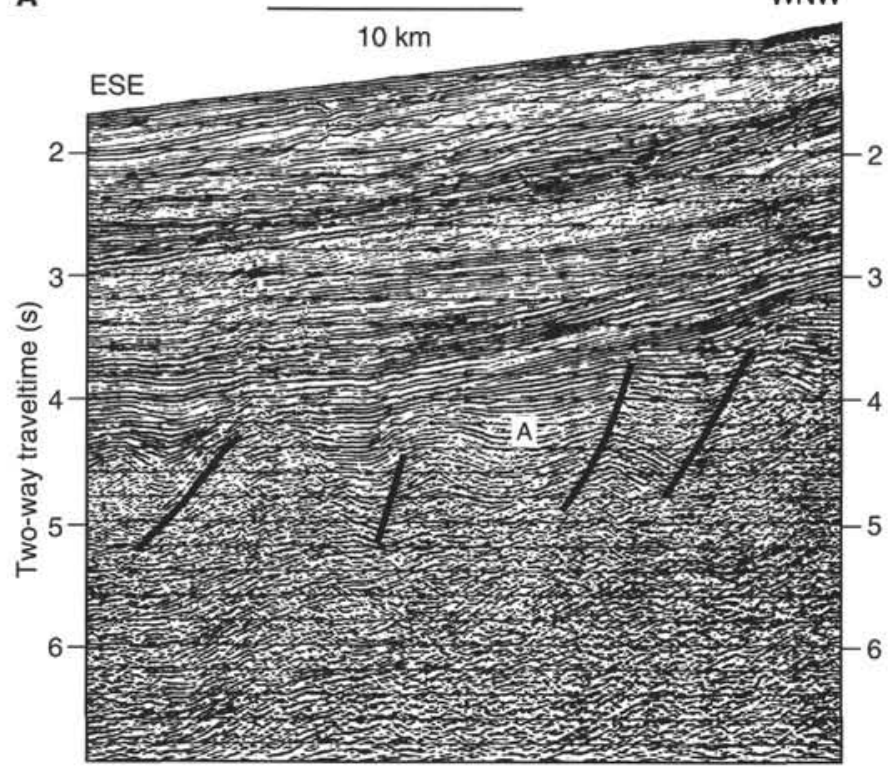

B

$E$

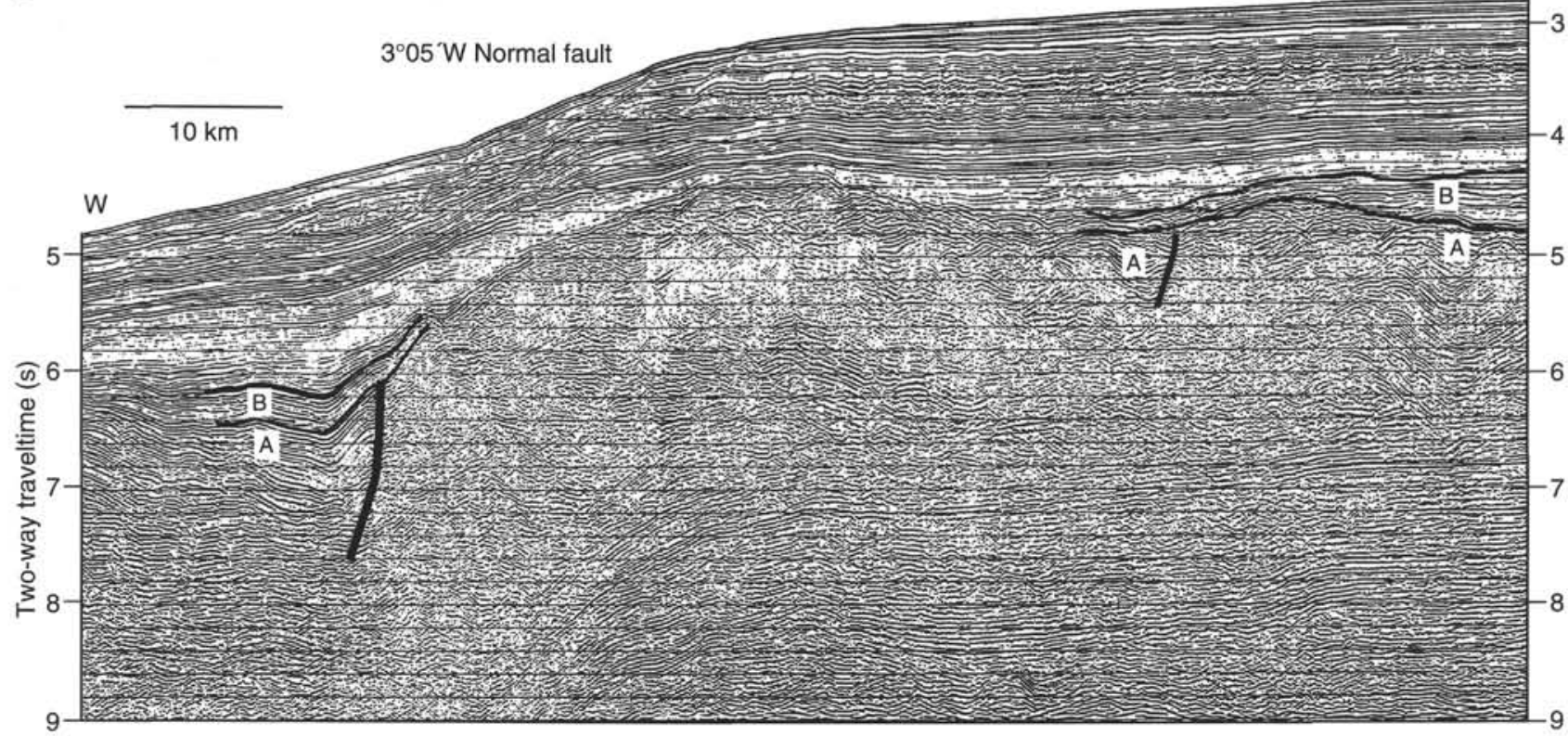

Figure 9. A. East-west MCS migrated section of Line MT12 across the Deep Ivorian Basin (see location on Fig. 2). The section shows a series of rotated blocks bounding half-grabens infilled by Unit A. The break-up unconformity is located between Units A and B. B. East-west MCS migrated section of Line MT07 across the Deep Ivorian Basin near the contact with the Marginal Ridge (see location on Fig. 2). Note the large vertical offset of the west dipping normal fault zone.

made of a thick pile of clastic sediments of Early Cretaceous age (Mascle et al., 1993). These sediments consist of dark shales, greenish lenticular to wavy bedded siltstones, and large-scale trough crossbedded sandstones. They are thought to have been deposited in a deltaic to prodeltaic environment (Fig. 19) (Guiraud et al., in press a, b). Integration of direct and video observations (Fig. 20) and of microtectonic sample analysis also has helped to better appraise the tectonic regime operative during the margin fabric. A multi-phase tectonic history, characterized by successive and distinct pre-, syn-, and postlithification microstructures, followed by late transform-related compression, has been documented from these data (Guiraud et al., in press a, b; Benkhelil et al., in press).
Finally, preliminary fission track analysis, recently performed on apatite grains from sampled sandstones, indicates a probable slope uncovering from Late Cretaceous to middle Eocene time (Bouillin et al., 1994). This erosional episode may be tentatively connected to general collapse due to differential subsidence between continental and oceanic crusts across a very narrow zone of transition.

\section{SUMMARY}

ODP Leg 159 is the first drilling cruise dedicated to assess the sedimentary, tectonic, and thermal processes as well as the subsid- 


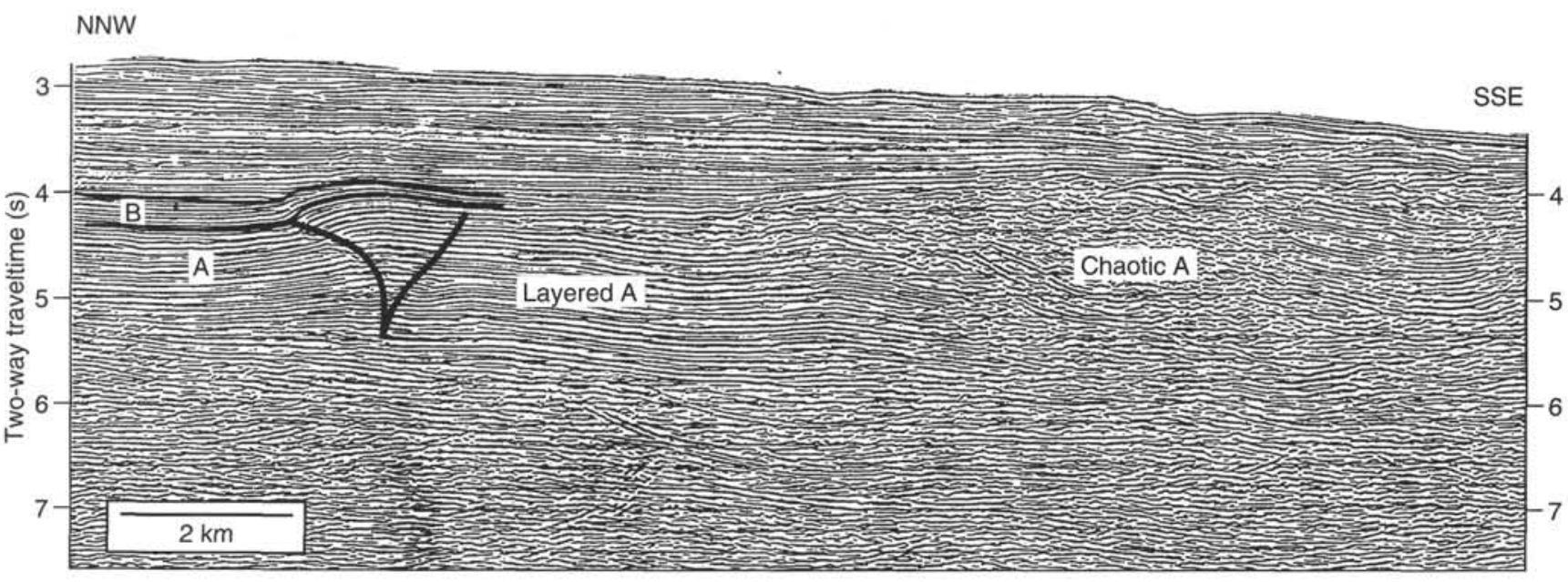

Figure 10. Migrated MCS section from Line MT03 across the eastern transform domain adjacent to the Ghanaian Platform (see location on Fig. 2). Note the reverse faulting that has deformed Units A and B within the proximal Ivorian Basin. Note also the change in seismic character of Unit A toward the south.

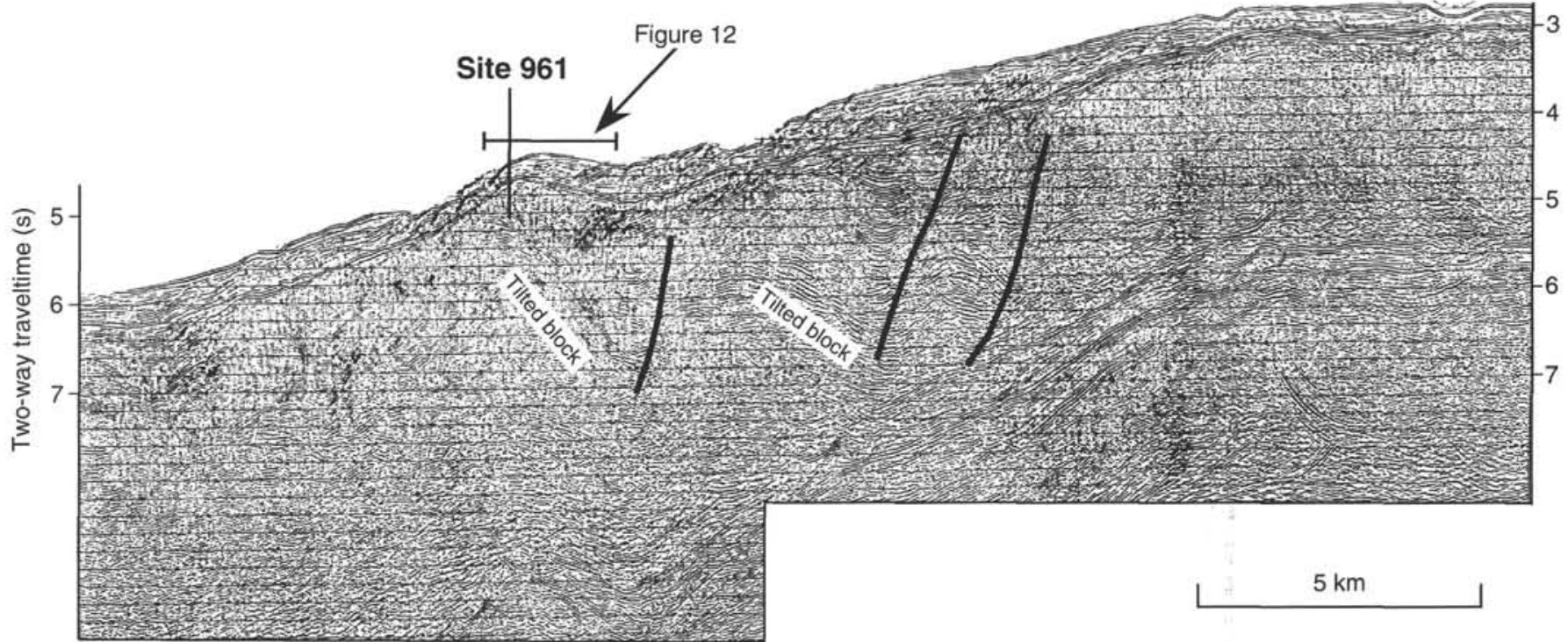

Figure 11. Migrated MCS section from Line MT05 recorded along strike of the marginal ridge, and showing several rotated blocks. See location on Figure 2.

ence history operating during and after continental transform margin formation, the challenge being to improve and develop geological models applied to this specific type of ocean-continent boundary.

The location of the Côte d'Ivoire-Ghana Transform Margin, within an equatorial region and located between two different oceanic basins (Central and South Atlantic) of different ages, also provided paleoceanographic potential for Leg 159. The marine geological and geophysical surveys briefly presented above, and with which Leg 159 was planned, have already provided noteworthy data making this segment of transform margin a well-investigated example of this type. It is anticipated that continuous coring and logging at all selected Leg 159 sites will answer many of the questions still in discussion and open new trends of investigation.

\section{ACKNOWLEDGMENTS}

We are indebted to the crews and marine technicians on board the different research vessels that participated in data acquisition and processing over the years. We give particular thanks to the scientific parties of the Equamarge ( $I$ and $I I)$, Equasis, Equaref, and Equanaute surveys. We also thank P. Lohmann and P. Clift for helpful improvements of the manuscript. IFREMER provided ship time and most of the technical support for the French party. Data processing and analyses were supported by CNRS-INSU and ORSTOM. Multichannel seismic reflection processing was completed at the seismic processing center of E.O.P.G. Strasbourg. GEMCO contribution no. 666.

\section{REFERENCES}

Basile, C., 1990. Analyse structurale et modélisation analogique d'une marge transformante: l'exemple de la marge profonde de Côte d'Ivoire-Ghana. Mém. Doc. CAESS Rennes, 39.

Basile, C., Brun, J.P., and Mascle, J., 1992. Structure et formation de la marge transformante de Côte d'Ivoire-Ghana: apports de la sismique réflexion et de la modelisation analogique. Bull. Soc. Geol. Fr., 163:207216.

Basile, C., Mascle, J., Auroux, C., Bouillin, J.P., Mascle, G., Goncalves de Souza, K., and le Groupe Equamarge, 1989. Une marge transformante 
type, la marge continentale de Côte d'Ivoire-Ghana: résultats préliminaires de la campagne Equamarge II, mars 88. C. R. Acad. Sci. Ser. 2, 308:997-1004.

Basile, C., Mascle, J., Popoff, M., Bouillin, J.P., and Mascle, G., 1993. The Côte d'Ivoire-Ghana transform margin: a marginal ridge structure deduced from seismic data. Tectonophysics, 222:1-19.

Benkhelil, J., Mascle, J., Guiraud, M., Basile, C., and the Equanaute scientific team, in press. "In situ" and sample observations of Cretaceous "syntransform" deformations along the Côte d'Ivoire-Ghana transform margin. Geo-Mar. Lett.

Blarez, E., 1986. La marge continentale de Côte d'Ivoire-Ghana: structure et évolution d'une marge continentale transformante [Ph.D. thesis]. Univ. Pierre et Marie Curie, Paris.

Blarez, E., and Mascle, J., 1988. Shallow structure and evolution of the Ivory Coast and Ghana transform margin. Mar. Pet. Geol., 5:54-64.

Blarez, E., Mascle, J., Affaton, P., Robert, C., Herbin, J.P., and Mascle, G., 1987. Géologie de la pente continentale ivoiro-ghanéenne: résultats de dragages de la campagne Equamarge. Bull. Soc. Geol. Fr., 5:877-885.

Bouillin, J.P., Poupeau, G., Riou, L., Sabil, N., Basile, C., Mascle, J., Mascle, G., and the Equanaute Scientific Party, 1994. La marge transformante de Côte d'Ivoire-Ghana: premières données thermo-chronologiques (campagne Equanaute, 1992). C. R. Acad. Sci. Ser. 2, 318:1365-1370.

Delteil, J.R., Valery, P., Montadert, C., Fondeur, C., Patriat, P., and Mascle, J., 1974. Continental margin in the northern part of the Gulf of Guinea. In Burk, C.A., and Drake, C.L. (Eds.), Geology of Continental Margins: New York (Springer), 297-311.

Emery, K.O., Uchupi, E., Phillips, J., Bowin, C., and Mascle, J., 1975. Continental margin off Western Africa: Angola to Sierra Leone. AAPG Bull., 59:2209-2265.

Fail, J.P., Montadert, L., Delteil, J.R., Valery, P., Patriat, P., and Schlich, R., 1970. Prolongation des zones de fractures de l'océan Atlantique dans le golfe de Guinée. Earth Planet. Sci. Lett., 7:413-419.

Guiraud, M., Benkhelil, J., Mascle, J., Basile. C., Mascle, G., and the Equanaute teams, in press a. Syn-rift to syn-transform deformation: evidences from deep-sea dives along the Côte d'Ivoire-Ghana Transform Margin. Geo-Mar. Lett.
Guiraud, M., Mascle, J., Benkhelil, J., Basile, C., Mascle, G., and Durand, M., in press b. Early Cretaceous sedimentary environment of the Côte d'Ivoire-Ghana Transform Margin as deduced from deep dives data. Geo-Mar. Lett.

Lamarche, G., Basile, C.. Mascle, J., and Sage, F., in press. The Côte d'Ivoire-Ghana transform margin: sedimentary and tectonic structure from multichannel seismic data. Geo-Mar. Lett.

Mascle, J., 1976. Le golfe de Guinée: un exemple d'évolution de marge atlantique en cisaillement. Mém. Soc. Geol. Fr., n.s., 128.

Mascle, J., Basile, C., Pontoise, B., and Sage, F., 1995. The Côte d'IvoireGhana Transform Margin: an example of an ocean-continent transform boundary. In Banda, E., Talwani, M., and Thorne, M. (Eds.), Rifted Ocean-Continent Boundaries, NATO ASI Ser.: Dordrecht (Kluwer), 327-339.

Mascle, J., Guiraud, M., Basile, C., Benkhelil, J., Bouillin, J.P., Cousin, M., and Mascle, G., 1993. La marge transformante de Côte d'Ivoire-Ghana: premiers résultats de la campagne Equanaute (Juin 1992). C. R. Acad. Sci. Ser. 2, 316:1255-1261.

Mascle, J., and the Scientific Party, 1994. Les marges continentales transformantes ouest-africaines - Côte d'Ivoire, Ghana, Guinée. Série Repères Océan, 5: Brest (IFREMER).

Mascle, J., and Smit, A.F.J., 1974. Nature de la pente continentale au sud du cap des Trois Pointes (Ghana, Afrique). C. R. Acad. Sci. Ser. 2, 279:121124.

Pontoise, B., Bonvalot, S., Mascle, J., and Basile, C., 1990. Structure crustale de la marge transformante de Côte d'Ivoire-Ghana déduite des observations de gravimétrie en mer. C. R. Acad. Sci. Ser. 2, 310:527-534.

Popoff, M., Raillard, S., Mascle, J., Auroux, C., Basile, C., and Equamarge Group, 1989. Analyse d'un segment de marge transformante du Ghana: résultats de la campagne Equamarge II (mars 1988). C. R. Acad. Sci. Ser. 2, 309:481-487.

Sage, F., 1994. Structure crustale d'une marge transformante et du domaine océanique adjacent: exemple de la marge de Côte d'Ivoire-Ghana [Ph.D. thesis]. Univ. Pierre et Marie Curie, Paris.

\section{Ms 159IR-103}

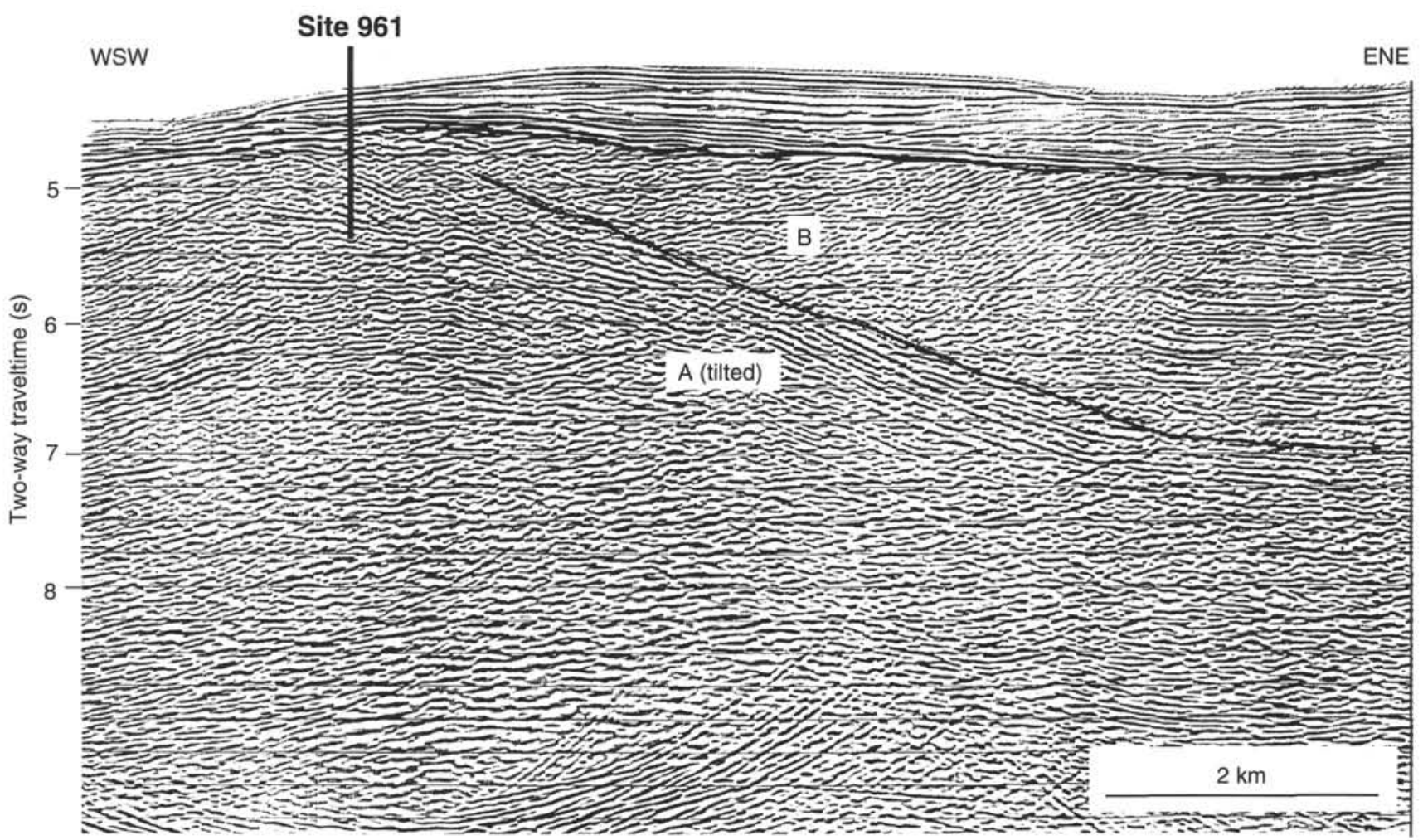

Figure 12. Migrated section from MCS Line MT05 over the ridge top (see location on Fig. 11). The section illustrates a rotated block and its bordering half-graben. Unit A infills the graben and is covered unconformably by Unit B, which is onlapped by post-tectonic sedimentary sequences. 


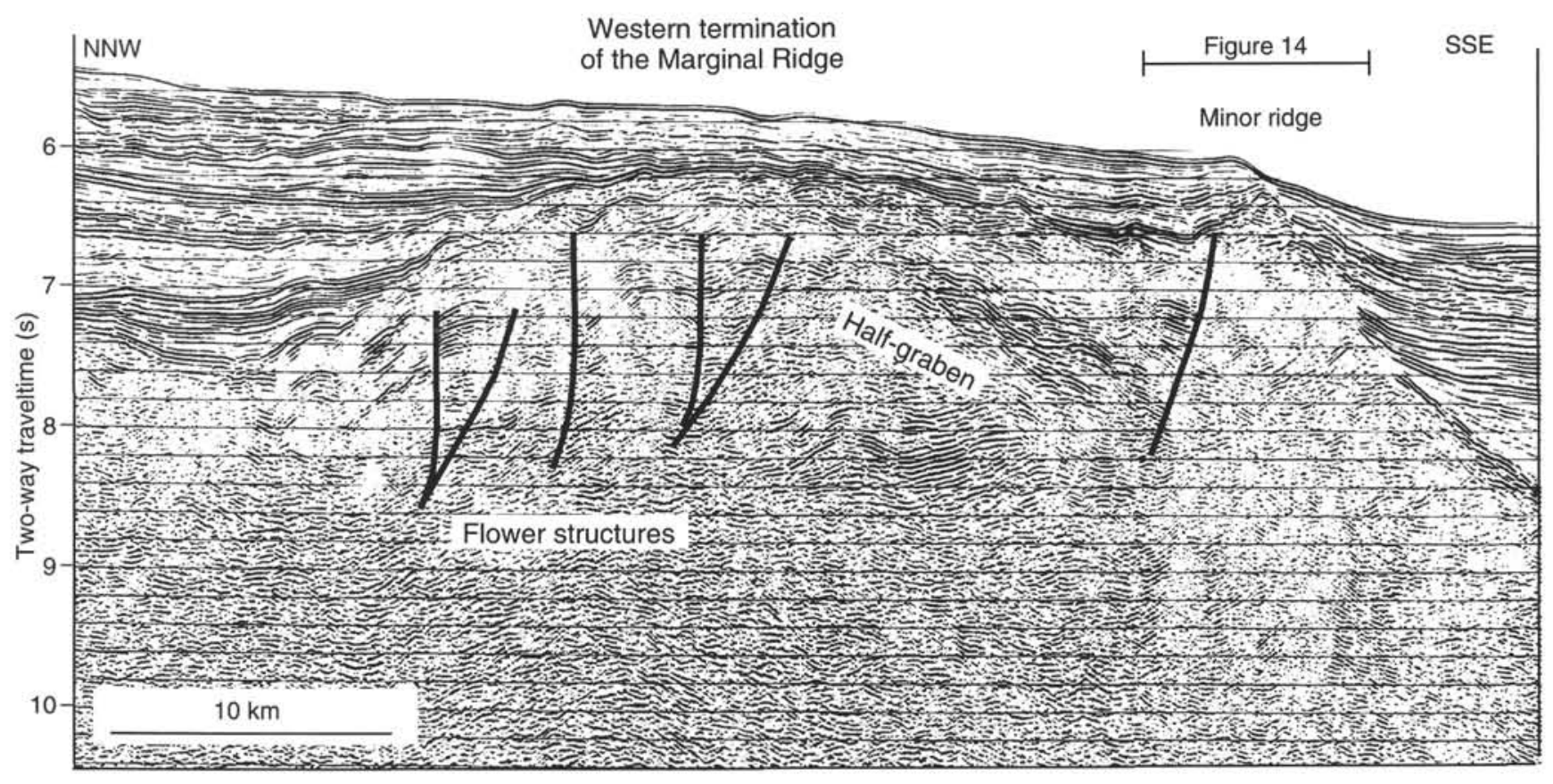

Figure 13. Migrated MCS section from Line MT01 across the westernmost and buried extension of the Marginal Ridge (see location on Fig. 2). The western termination of the ridge is deformed by several positive flower structures. Southward, a minor ridge is emplaced near the continent-ocean boundary. Note the wide east-west half-graben that bounds the minor ridge to the north.

Figure 14. Enlarged section from migrated MCS Line MT01 across the first minor ridge located between the Marginal Ridge and the Romanche Fracture Zone (see location on Fig. 13). Site 962 location is shown.

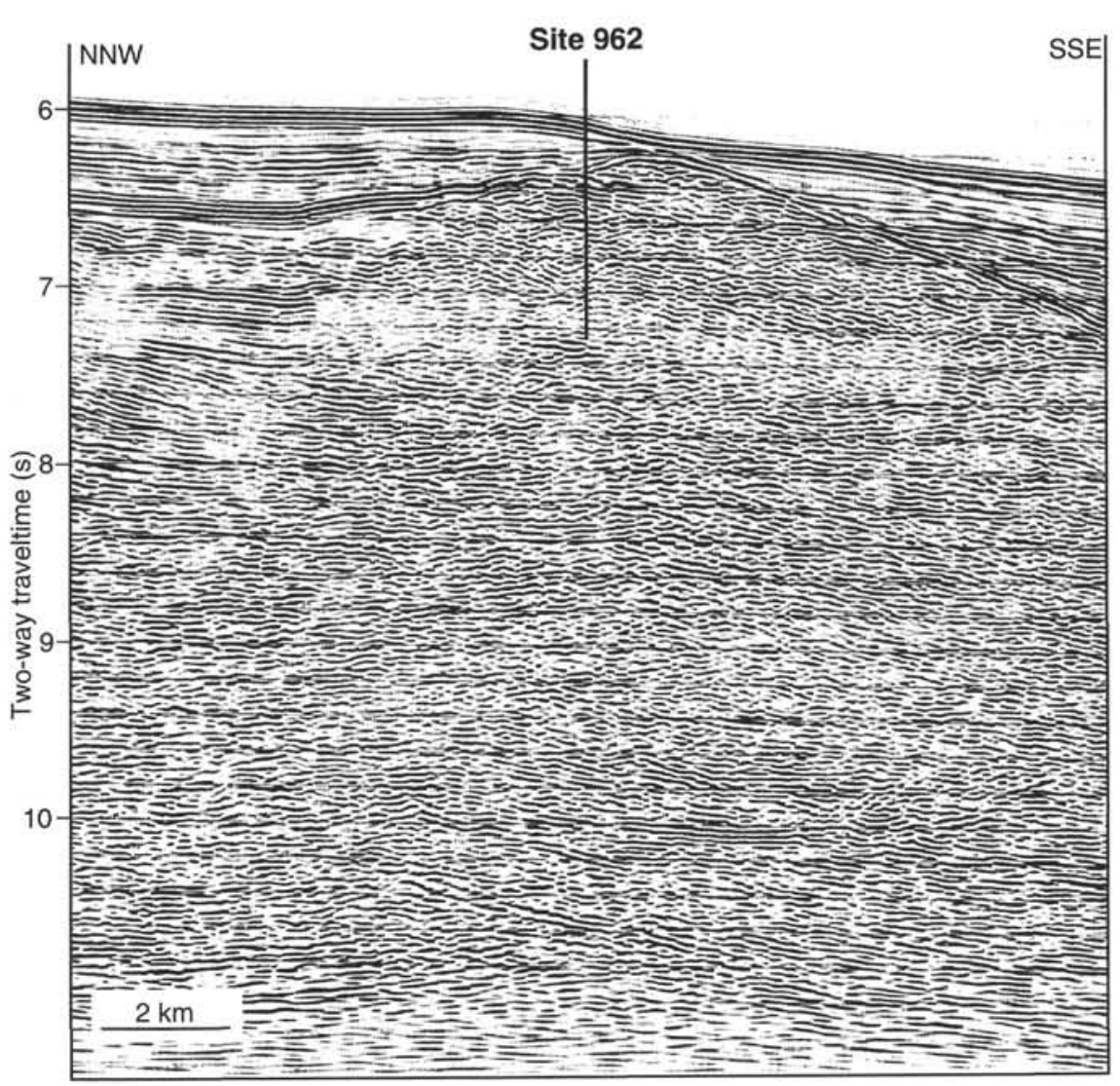




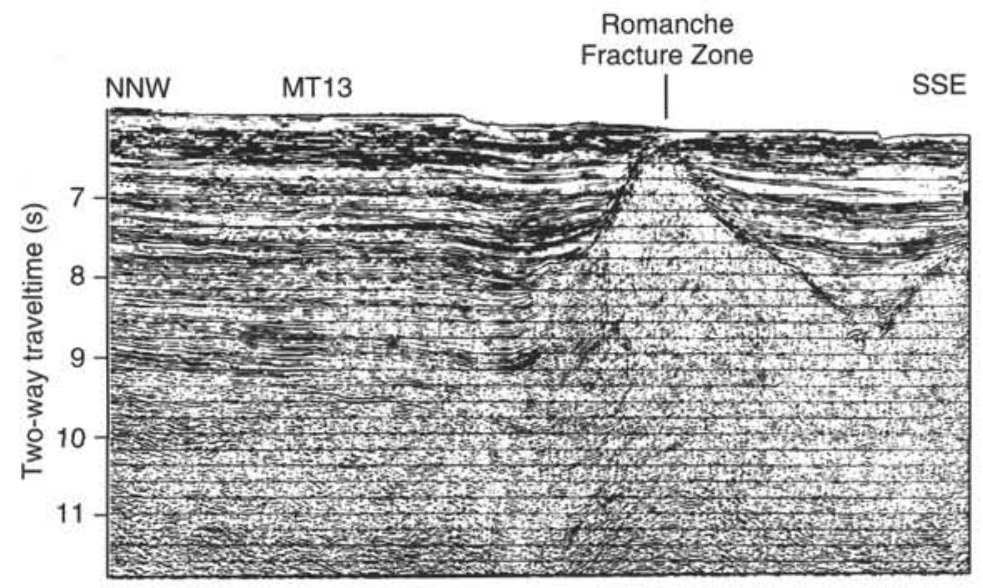

Figure 15. Two MCS migrated sections across basement ridges detected along the Romanche Fracture Zone west of the transform margin. Lines MT13 (top) and MT14 (bottom) are located on Figure 2.

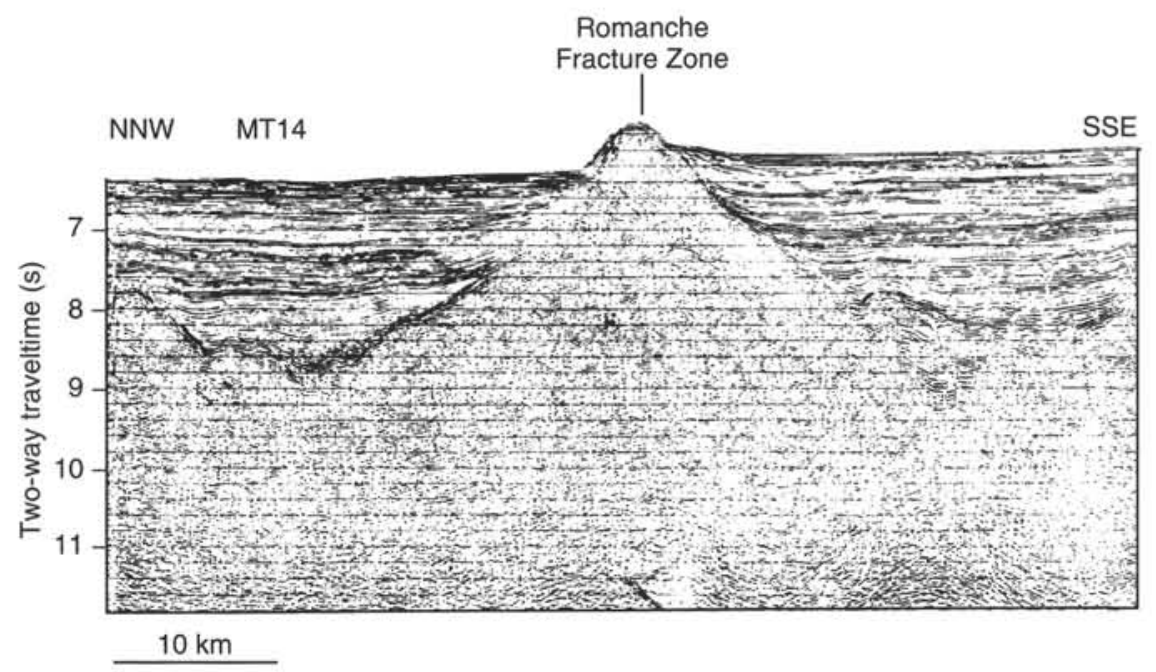

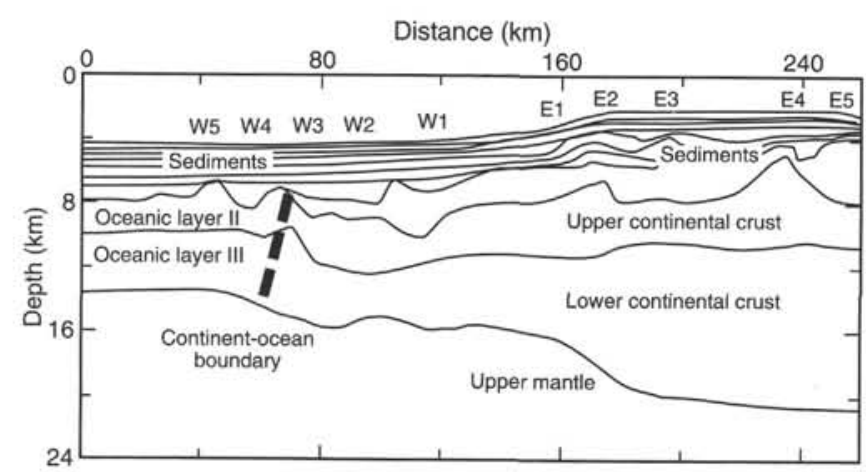

Figure 16. East-west crustal section across the Deep Ivorian Basin, based on seismic wide-angle data (after Sage, 1994). E1 through E5 and W1 through W5 refer to OBS locations along strike on MCS Line MT07. El is located above the normal fault scarp seen in Figure 9B.

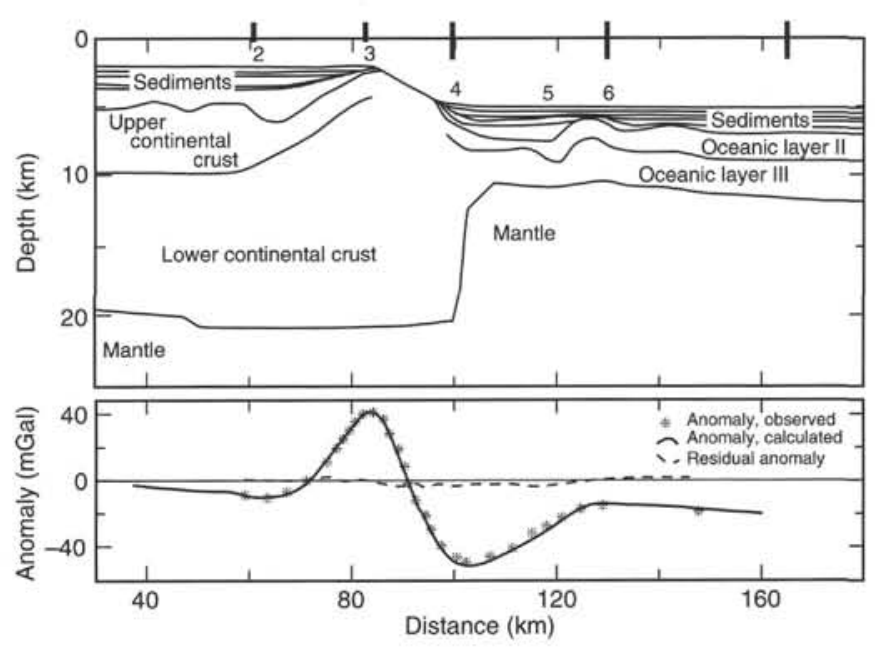

Figure 17. North-south crustal section, based on gravity modeling and wideangle seismic data, across the Deep Ivorian Basin to the north, the Marginal Ridge and the oceanic abyssal plain to the south (after Sage, 1994). Note the sharp ocean-continent transition, less than $10 \mathrm{~km}$ in width, and the very steep Moho gradient between the continental domain (crustal thickness on the order of 18-20 km) and the oceanic crust (on the order of 4-6 km). Thick vertical lines indicate perpendicular refraction lines. Numbers 2 through 6 indicate OBS locations. 


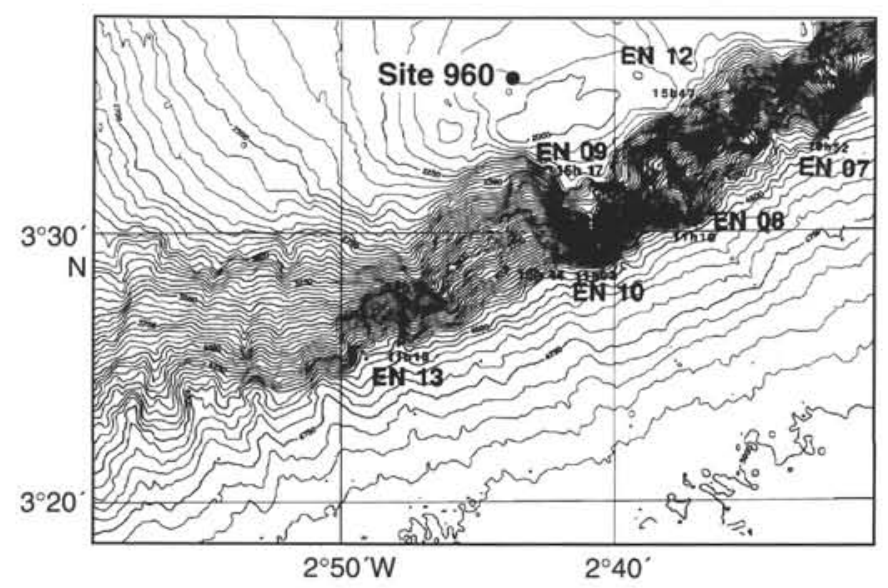

Figure 18. Location of Equanaute (EN) deep dives along the southern slope of the Côte d'Ivoire-Ghana Marginal Ridge (western domain). Most of the dives were performed between $4600 \mathrm{~m}$ and $2500 \mathrm{~m}$ water depth. About 5 to 6 $\mathrm{km}$ of seafloor was visited and 12 to 15 in situ rock samples were retrieved during each dive. 


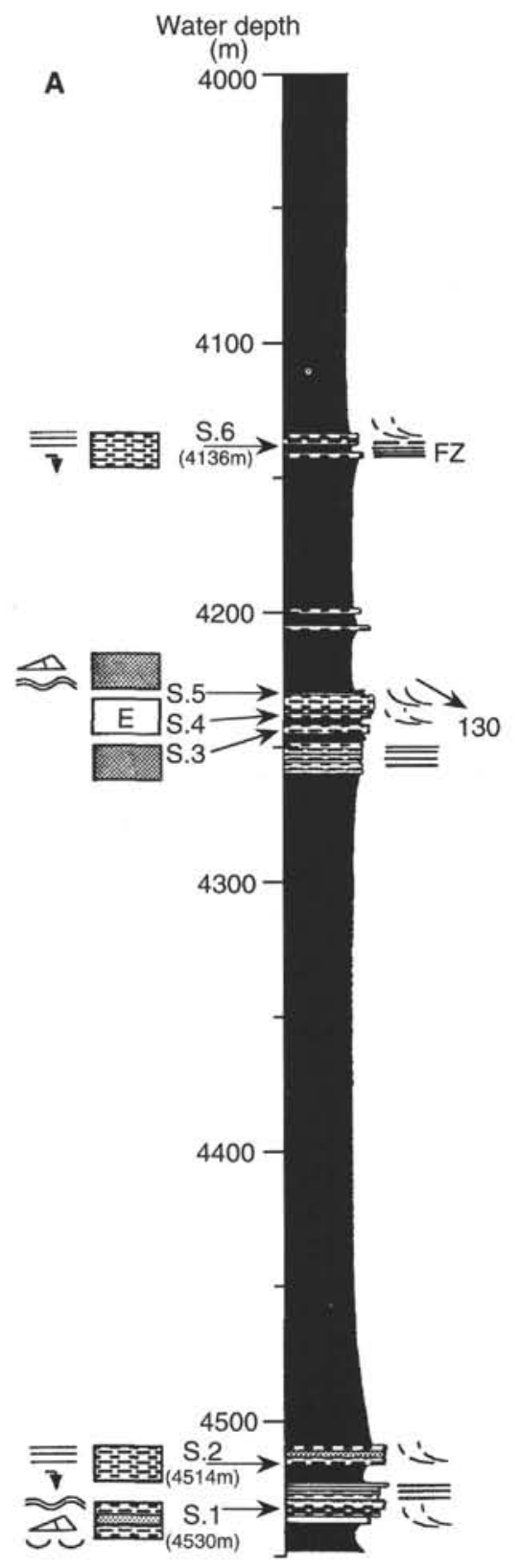

B

Dive EN 13

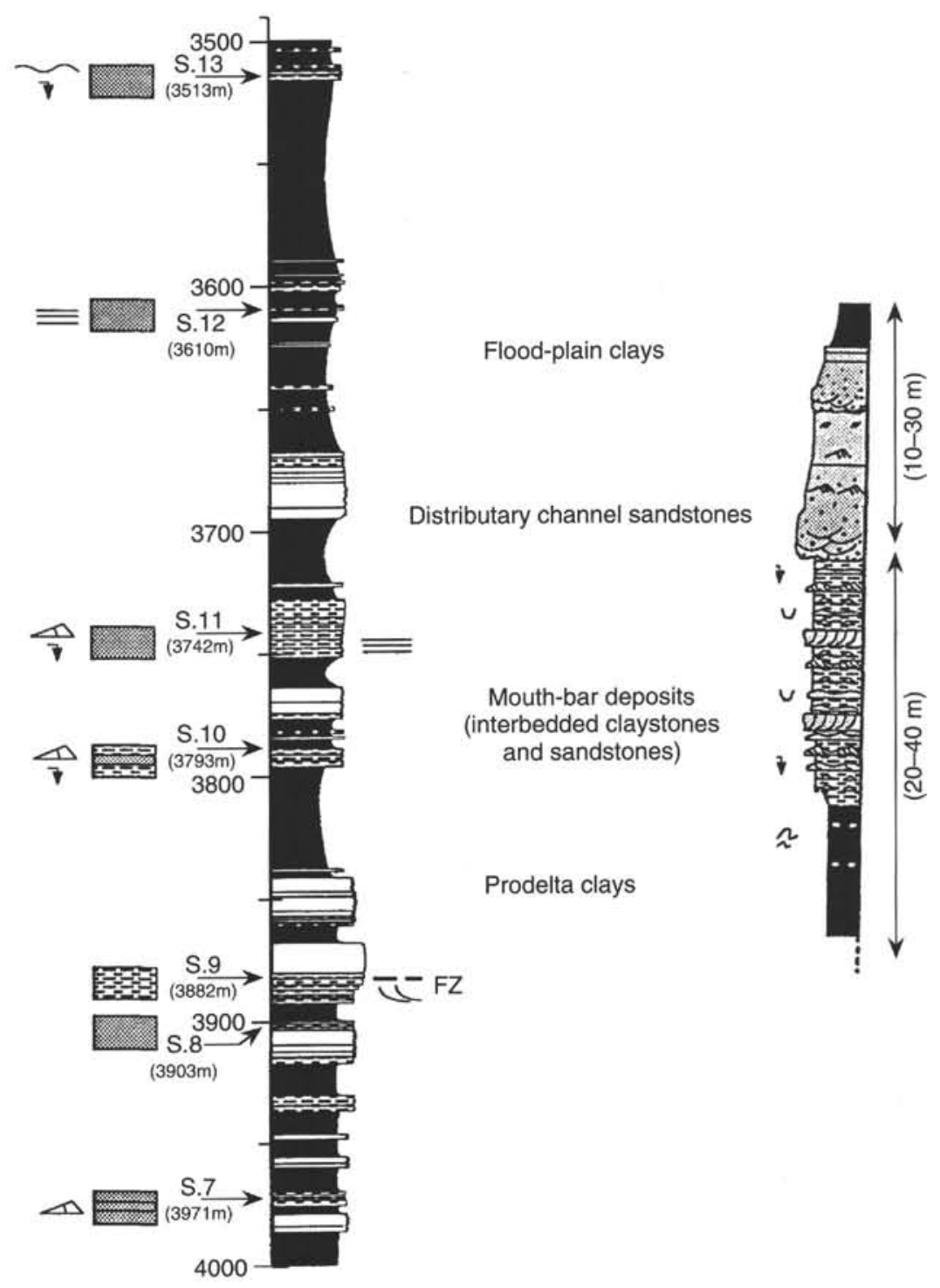

Figure 19. A. Example of a lithologic log derived from observations and sampling during dive EN13 (after Guiraud et al., in press a, b); S1 through S13 refer to sample locations. B. Synthetic sedimentary sequence likely valid for most of Unit A, exposed along the Marginal Ridge southern slope, as deduced from integration of dive observations and in situ sampling. 
A

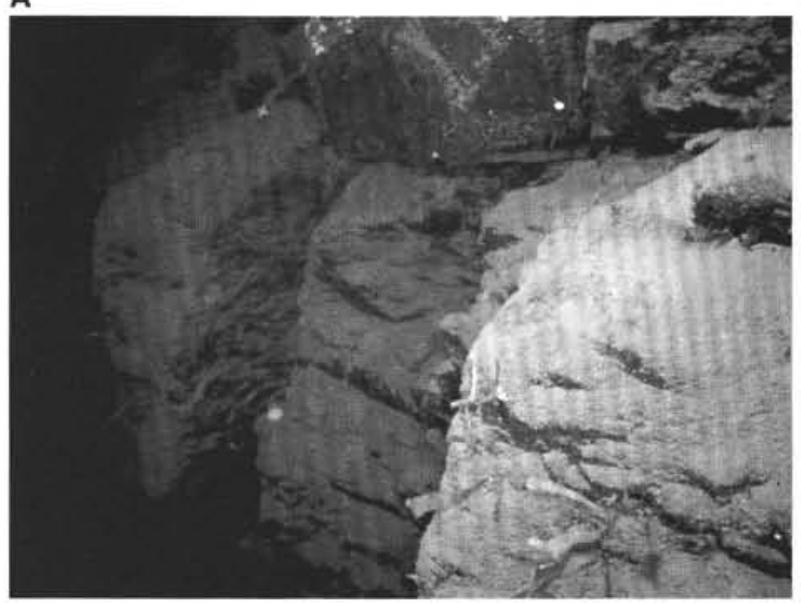

c

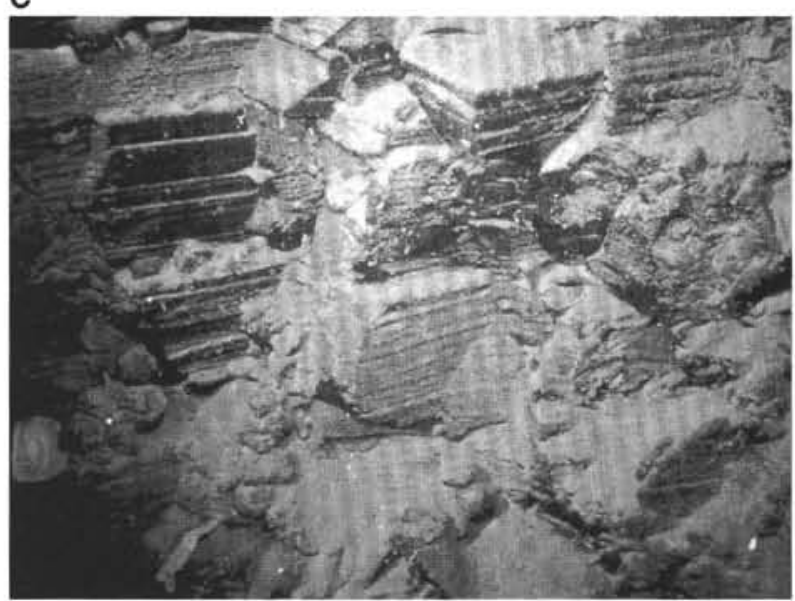

E

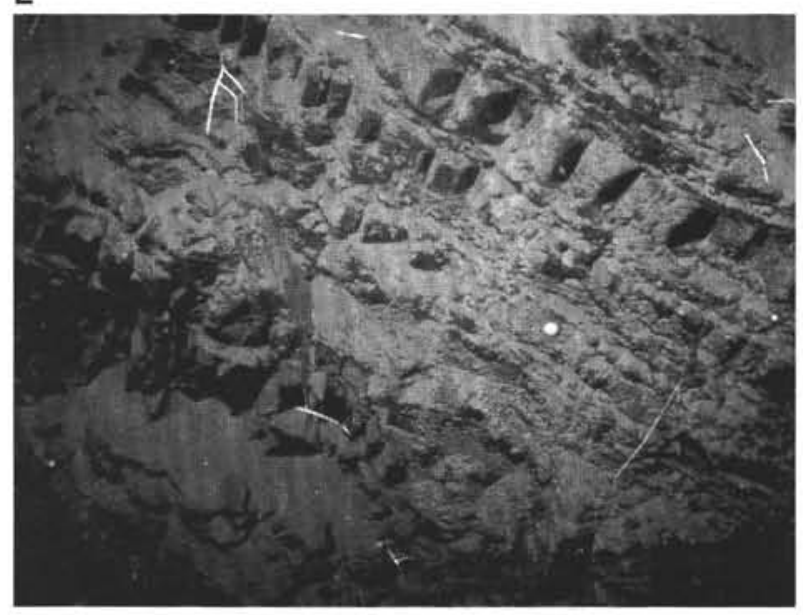

B

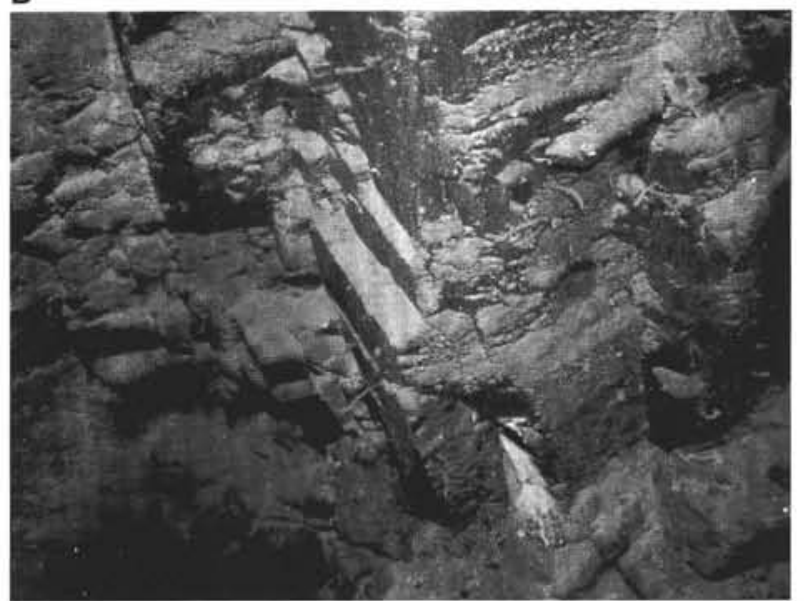

D

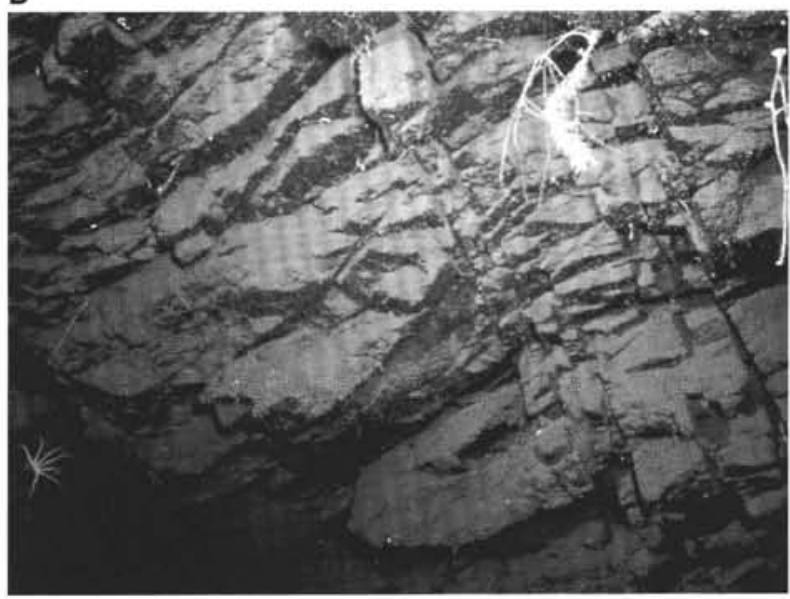

F

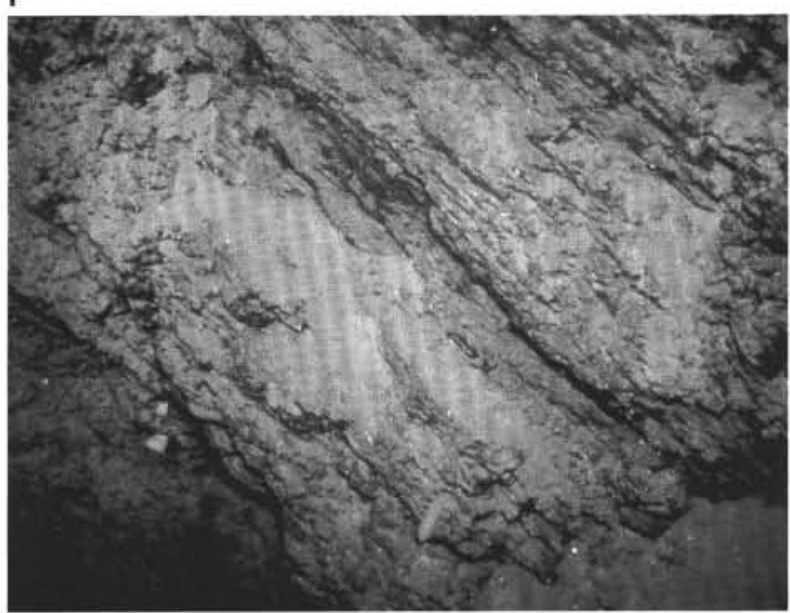

Figure 20. Selected photographs of exposed outcrops observed during deep dives along the Marginal Ridge slope. A. Massive sandstones (dive EN6 at 3497 m). B. Massive sandstone cliff cut by $\mathrm{N} 40^{\circ}$ trending fault (dive EN8 at $3734 \mathrm{~m}$ ). C. Fine-grained sandstones to siltstones cut by orthogonal brittle joints (dive EN7 at $4000 \mathrm{~m}$ ). D. Fractured and folded sandstones (dive EN7 at $3012 \mathrm{~m}$ ). E. Fine-grained sandstones and siltstones tilted toward the south (dive EN12 at $3347 \mathrm{~m}$ ). F. Alternating siltstones and claystones tilted toward the southeast (dive EN13 at $4525 \mathrm{~m}$ ). 